\title{
ПЯТИДЕСЯТИЛЕТИЕ СО ДНЯ РОЖДЕНИЯ Д-РА ЯНА БОУШКИ
}

25. XI. 1958 г. Д-ру Яну Боушке, выдаюпемуся чехословацкому геомагнитисту, псполняется пятыесят лет. Родился он в г. Собеслав п по окончании курса наук реф. реальной глмназии в г. Иглава поступил на естественный факультет Карлова университета в Праге, где в 1929-1935 годах изучал математику и физику. На основании диссертадия на тему ,Влияние кручения волокон на измерения с помощью теодолита" в 1935 г. ему была прпсуждена ученая степень доктора естественных наук. После ото́ывания воинской повинности, он с 1938 г. работал в Государственной метеорологической и астрофизической обсерваторип в п. Стара Дяла (ныне Геофизическая лабораторня САН, Гурбаново), в Словакни. В нояб̄ре 1938 г. он был переведен в штаты Государственной астрономической обсерваторпи в Праге, однако же в действительности работал уже в Государственном геофизнческом институте (ГГН) в Праге вплоть до 1942 г., когда этот институт был упразднен немепкими оккупантами. После зтого последовало прннудптельное включение на раб̈оту в Геофизпческий институт немецкого Карлова университета вплоть до 1940 г. После освобождения нашей родины в мае 1945 г., Государственный геофизический пнститут возойновнл свою деятельность й Д-ру Я. Боушке была поручена организация геомагнитного отделения и его руководства. После слияния ГГИ с Центральным физическим институтом, в дскао́ре 1950 г. он работал там вплоть до 1.I. 1953 г., когда был создан Геофизидеский ннститут ЧСАН, куда он был переведен и руководителем которого он стал l. VII. 1957 r.

Д-р Боушка внес свой крупный вклад в дело создания Чехословапкой геомагнитной обсерваторпи в г. Пругопице у Праги, которая ныне снаб́жена новсйпими прпборами п вклюqена в международную сеть геомагнитных об́серваторий. По испытательной эксплуатации названная обсерваторня работает регулярно, начнная с 1. VII. 1946 r. а результаты ее работы пздаются с 1952 г. в хорошо известных годичных бюллетенях. По предложению Д-ра Боушки и под его руководством была создана также скорорегистрирующая геомагнитная станция в п. Будіов у Г. Прахатице, надавшая свою работу 1. І. 1958 г. Эта станция была создана, в частности, для изучения микроструктуры геомагнитного поля во времени. Из писла разлгчных прпбооров, установленных на станции, следует в особенности упомлнуть трехкомпонснтног аппаратуру с әлмг. зондами, развитую по проекту Д-ра Боушки нар. предпр. „Градиштян" в г. Уг. Градиште (коллективом сотрудников под руководством инж. И. Кнюорка).

Нз большого числа научных работ юбиллра прежде всего следует назвать полное геомагнитное картирование в Чехпи и Моравии, осуществленное совместно с коллективом сотрудников в 1946-1948 годах. Резудытаты әтих работ приведены в труде „,Распределение гемагнитного поля в тешских землях к әпохе 1950,0" (Геофизический сборник 1955 , работа No 30 ). Из ряда дальнейших публикаций Д-ра Боунки упомянем, в тастности, работы, касаюпиеся непрерывного магнитного профиля местности п геофизическо-геологитеских исследований геомагнитных региональных аномалий. Равным об́разом важное значение имеют международиые сравнительные геомагнитные измерения и увязочные пзмерения на границах стран-соседей ЧСР, осуществленные по его иницитатве.

Нашу книжную наутную литературу Д-р Боушка обогатил кроме иных публикаций книгой на тему: ,, Земной магнетизм“" (Путь к знаниям, т. 39).

Из числа различных постов, запимаемшх юбпляром, следует упомянуть, что он является научним секретарем Комисспи по проведению МГГ при ЧСАН и начальником техословацкой геомагитной постоянной службы. Он состоит пленом паучных советов редакционных коллегий, членом Комиссии по вопросам геодезии и геофизики при ЧСАН и т. д. Несколько раз он был представнтелем чехословадкой геофизикп на совещаниях за рубенжом.

В заключение мы пожелаем юбиляру много дальнейших лет плодотворной и успешпой работы научного п организацнонного характера.

Jan Picha 